GLOBAL JOURNAL OF GEOLOGICAL SCIENCES VOL. 17, 2019: 75-83

COPYRIGHT@ BACHUDO SCIENCE CO. LTD PRINTED IN NIGERIA ISSN 1596-6798 www.globaljournalseries.com, Email: info@globaljournalseries.com

\title{
PRELIMINARY REVIEW OF THE GEOLOGY OF THE HORNBLENDE BIOTITE GNEISSES OF OBUDU PLATEAU SOUTHEASTERN NIGERIA
}

IFEOMA AGBI AND BARTH N. EKWUEME

(Received 25 September 2018; Revision Accepted 9 November 2018)

\begin{abstract}
The Obudu Plateau, southeastern Nigeria is dominantly underlain by gneissose rocks with migmatitic characteristics, one of which is the hornblende-biotite gneiss. The gneisses are banded with quartz and plagioclase as the major minerals in the leucosome while hornblende and biotite occur in the palaeosome. Geochemically, the rocks are enriched in silica and alumina with an average of $71.6 \mathrm{wt} \%$ and $14 \mathrm{wt} \%$ respectively. Geochemical plots indicate that they are calc-alkaline to tholeiitic in character and derived from protholiths of igneous origin with minor sedimentary input.
\end{abstract}

KEYWORDS: Obudu Plateau, migmatitic gneiss, calc-alkaline

\section{INTRODUCTION}

Migmatitic Gneisses belong to one of the four major rock types in the Nigerian Basement Complex, specifically the Migmatite - gneiss - quartzite complex (Rahaman,1988). Rocks of this complex are presumed to be the oldest and have been dated to be pre-Pan African in age (2.8 -1.3Ga; Ekwueme 1990). The migmatitic nature of the rocks reflects the nature of the deformation and high-grade metamorphism these rocks have been subjected to. The Nigerian Basement Complex is said to have evolved through a series of tectonothermal events of which at least three episodes of deformation have been recognised (Grant, 1970; Rahaman and Lancelot, 1984; Dada,1998).

Ifeoma Agbi, Department of Physics/Geology/Physics, Alex Ekwueme Federal University Ndufu-Alike, Ikwo, Nigeria. Barth N. Ekwueme, Department of Geology, University of Calabar, Calabar, Nigeria.
In Southeastern Nigeria, the Obudu Plateau is one of the exposures of the Precambrian basement rocks (Figure 1) and belongs to the Nigerian topographic sheet 291 (Obudu). This sheet has been studied in sections; NE, NW, SE, SW by various workers (e.g Orajaka, 1964; Ekwueme, 1994; Ukaegbu, 2003; Ukwang et. al., 2003; Ephraim, 2009; Obioha and Ekwueme, 2011) and these workers have grouped and described the migmatite gneisses in the area as garnet - sillimanite gneiss, garnet - hornblende gneiss, or plainly as migmatite gneiss. This study is an attempt to take a holistic look at the Obudu sheet and present a preliminary account of the petrology and geochemistry of the hornblende-biotite gneiss in the area. 


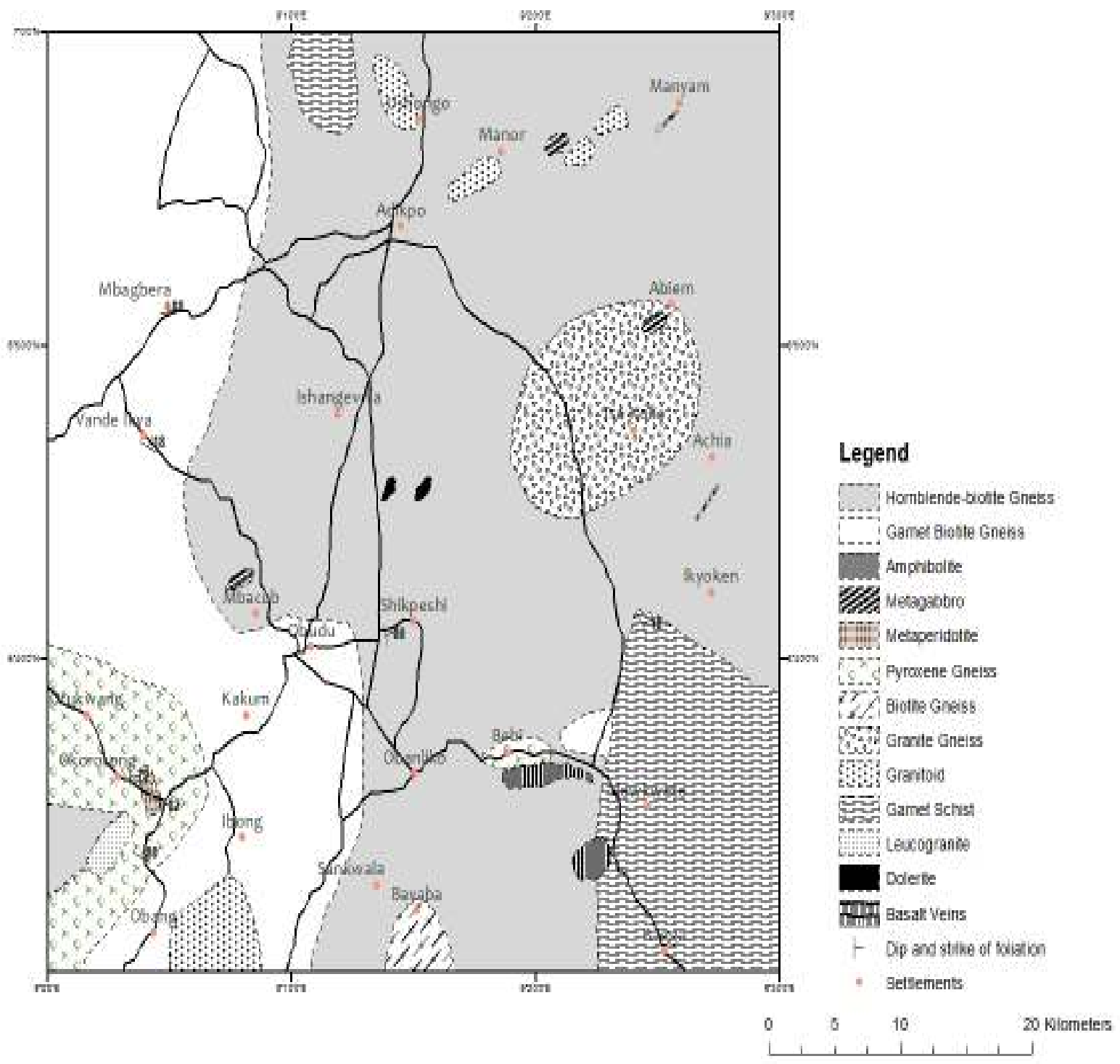

Figure 1: Geologic map of Nigeria showing the study area (modified from Woakes et al., 1987)

\section{Regional Tectonics}

The Obudu Plateau is one of the outcrops of the Nigerian Precambrian basement in southeastern Nigeria. It is an extension of the Bamenda Massif into southeastern Nigeria. The lithological variations in the region include high grade metamorphic rocks consisting dominantly of gneisses and schists that have been migmatised and intruded by unmetamorphosed granites, dolerites, aplites and quartzo-feldspathic veins. Also associated with these rocks are minor occurrences of metagabbros, amphibolites and metaquartzites. Archaean, Eburnean and Pan-African ages have been obtained from rocks of these region (Ekwueme, 2003; Ukwang et al., 2012). The similarity between the ages and lithology of rocks of southeastern Nigerian basement to rocks of the northern Cameroon basement and the Central African Fold Belt (Ekwueme, 2003, Ephraim 2005) have led workers to suggest that the southeastern Nigerian basement evolutionary history is linked to the Pan-African mobile belt in Central Africa. According to Toteu et al., (2004), the Pan-African belt in Central Africa is due to a continent-continent collision that involved the northern edge of the Congo craton as the passive margin and the Adamawa-Yadé and western Cameroon domain as the active margin.

\section{Field Occurrence and Characteristics}

The study area is underlain by gneisses and schists within which are bodies of amphibolites, metagabbros, dolerites and granitoids. The dominant foliation trend is $\mathrm{N}-\mathrm{S}$ to NE-SW with an average dip of 55 degrees. The schists are restricted to the southeastern part of the study area and are migmatitic in nature. Where they occur within the gneisses, they are seen underlying riverbeds and are extensively weathered. 
Gneissose rocks cover about two-thirds of the study area and consist of pyroxene gneiss, garnet-biotitegneiss, hornblende-biotite gneiss and biotite gneiss (Figure 2). Generally, the gneissose rocks are mesocratic and medium grained and exhibit conspicuous alteration of light and dark coloured bands. The hornblende-biotite gneiss constitutes the dominant rock type in the study area and have been described in other publications as migmatitic gneiss (e.g Ephraim, 2009). It generally consists of the metamorphic host rock (palaeosome) and leucocratic injections (leucosomes). The leucocratic injections consist mainly of quartz and feldspar and often occur as elongate continuous bands giving the rock a banded appearance. At other places, the leucosomes form coarser pegmatitic veins that dissect the rock irregularly. Other deformation structures include foliations, augen structures, pinch and swell structures. In the Shikpeshe mountains and lykoken hill regions where extensive partial melting was observed, large regions of the rocks were almost totally felsic and could be described as quartzite. The banding is broader and rocks show ptygmatic folding, minor folds and minor shear zones (Figure 3). At the Amire River bed Manyam and Achia, the hornblende-biotite gneiss has been intruded by multiple dolerite dykes that range from 20 to $130 \mathrm{~cm}$ in width and trend NE-SW. Generally, the hornblende-biotite gneiss occurs as highs and show extensive weathering such that fresh outcrops are scarce.

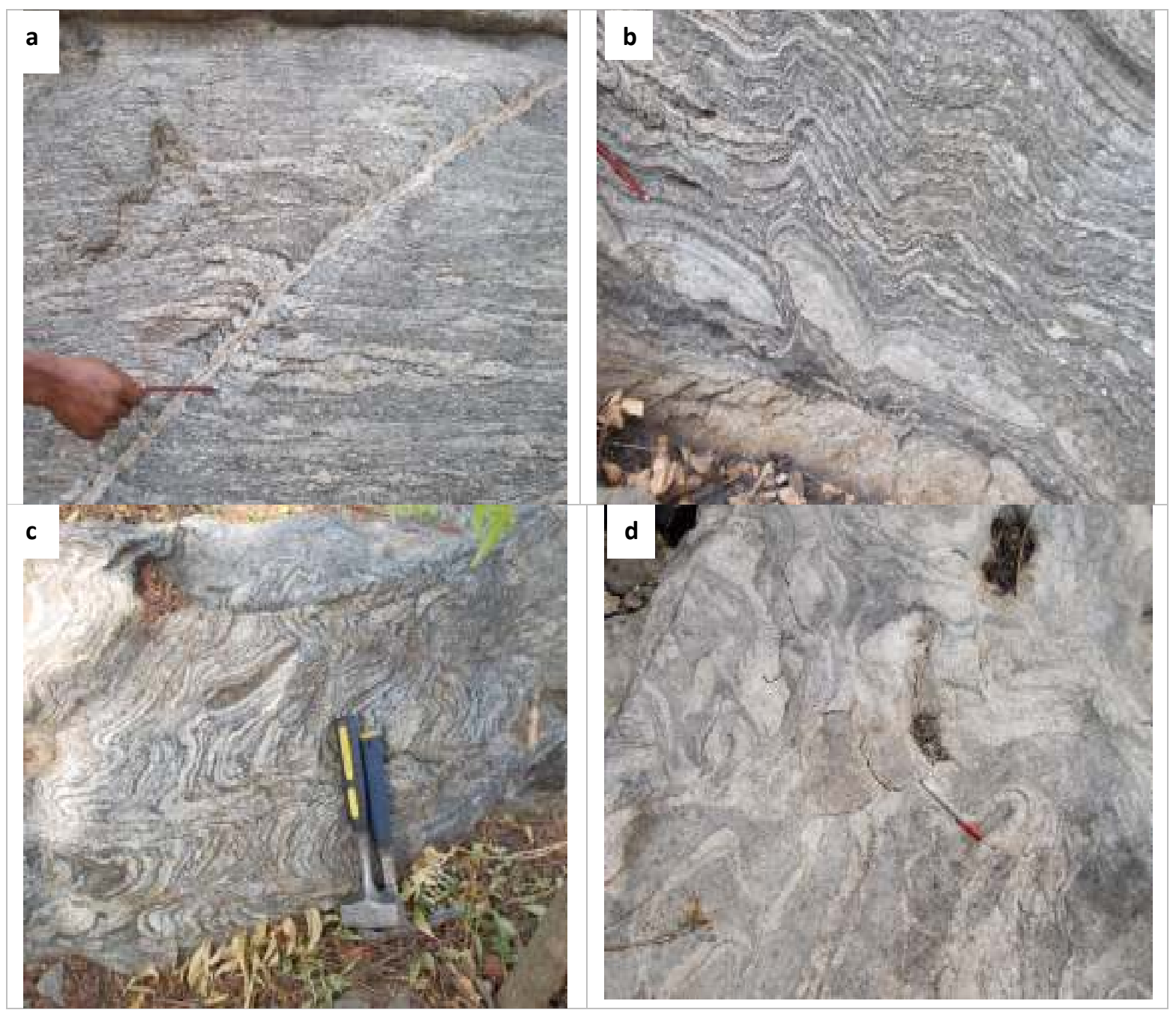

Figure 3. Field characteristics of the hornblende biotite gneiss. (a) Minor shear zone (b) pinch and swell structures (c)micro folds (d) contorted foliation 
Table 1: Average Modal Composition of the Hornblende -Biotite Gneiss.

\begin{tabular}{|l|l|l|l|l|l|l|l|}
\hline & ADP-06 & ADP-08 & ADP-09 & ADP-24 & ADP-25 & IA-08 & IA-09 \\
\hline Quartz & 10 & 50 & 30 & 30 & 30 & 28 & 30 \\
\hline Plagioclase & 30 & 20 & 30 & 25 & 15 & 30 & 20 \\
\hline K-Feldspar & - & - & 5 & 7 & 20 & 5 & 20 \\
\hline Biotite & - & 15 & 10 & 10 & 20 & 15 & 20 \\
\hline Muscovite & - & - & - & - & 5 & - & 5 \\
\hline Hornblende & 50 & 10 & 10 & 20 & - & 10 & - \\
\hline Orthopyroxene & 5 & - & 10 & - & - & 5 & - \\
\hline Clinopyroxene & - & - & - & - & - & 5 & - \\
\hline Sillimanite & - & - & - & - & 5 & - & - \\
\hline Sphene & - & - & - & - & 1 & 1 & - \\
\hline Opaques & 5 & 3 & 5 & 8 & 2 & 1 & 5 \\
\hline
\end{tabular}

\section{Petrography of the Hornblende-biotite Gneiss}

Table 1 shows the modal composition of the hornblende-biotite gneiss. The leucocratic mineral phases are composed predominantly of quartz and plagioclase. The quartz grains show undulose extinction and consist of irregularly shaped crystals and in some samples occurs as sub-grains. Inclusions of biotite, plagioclase and opaques occur in some grains and quartz also occurs as inclusions in pyroxene. Quartz is less common in the melanocratic mineral phases.

Plagioclase in this rock has an average modal percentage of about $27 \%$ with a mean plagioclase composition of $\mathrm{An}_{43}$ (andesine) and exhibits twinning on albite laws. A few shows combined albite and carlsbard twining as well as deformation twins. Core to rim extinction was also observed in a few crystals. Sericitization of the plagioclase mineral is prevalent and the grains are generally subhedral. K-feldspar crystals are subordinate to plagioclase and are mostly microcline.

Biotite occurs in sections as lath shaped crystals showing perfect cleavages in one-direction. It is strongly pleochroic from light brown to dark/orange brown. The biotite grains make up about $15 \%$ of the hornblende- biotite gneiss volume. The biotite grains along with hornblende define the foliations of these rocks.

Hornblende is a common mineral in these rocks but is however absent in some samples from the Shikpeshie and Ikyoken hill region (in these areas, the rocks show high level of partial melting). The grains are mostly anhedral and strongly pleochroic from green to greenish brown. Most of the crystals encountered show inclined extinctions with angles between $18^{\circ}$ and $22^{\circ}$. A few basal sections showing characteristic cleavage were also observed.

Orthopyroxene occurs as a minor constituent of some samples. The grains are subhedral to anhedral and in some samples contain inclusions of quartz, plagioclase and hornblende. Some of the crystals show one clear cleavage trace with parallel extinction. Several, however show two cleavage traces that intersect almost at right angles.

Sillimanite and muscovite crystals occur in the rocks that lack hornblende as a minor constituent. The sillimanite occurs as swirled fine fibrous crystals mostly alongside with biotite. Other accessory minerals are sphene and opaques. The opaques occur mostly as irregularly shaped crystals. 
Table 2. Major element oxides and Niggli values of hornblende biotite rocks from Obudu

\begin{tabular}{|c|c|c|c|c|c|c|c|c|c|c|c|c|c|}
\hline & 1 & 2 & 3 & 4 & 5 & 6 & 7 & 8 & 9 & 10 & 11 & 12 & 13 \\
\hline Oxides & GHG1 & GHG2 & GHG3 & NG1 & GB3 & NK1 & BK4 & D 11.4 & D26.3 & BGM1 & BGM2 & UK1 & UK2 \\
\hline $\mathrm{SiO}_{2}$ & 71.8 & 68.77 & 72.06 & 74.98 & 71.11 & 72.63 & 72.11 & 72.29 & 72.8 & 69.54 & 70.33 & 69.96 & 71.45 \\
\hline $\mathrm{TiO}_{2}$ & 0.45 & 0.39 & 0.2 & 0.17 & 1.08 & 0.84 & 0.89 & 0.42 & 0.12 & 0.39 & 0.22 & 0.54 & 0.24 \\
\hline $\mathrm{Al}_{2} \mathrm{O}_{3}$ & 14.89 & 15.63 & 12.68 & 13.1 & 14.02 & 13.42 & 13.99 & 13.28 & 14.5 & 14.01 & 14.23 & 13.39 & 15.29 \\
\hline $\mathrm{Fe}_{2} \mathrm{O}_{3 \text { (Tot) }}$ & 1.64 & 2.41 & 0.65 & 1.05 & 2.88 & 2.54 & 2.58 & 4.34 & 2.03 & 3.56 & 2.75 & 5.99 & 2.22 \\
\hline $\mathrm{MnO}$ & 0.02 & 0.03 & 0.02 & 0.01 & 0.01 & 0.01 & 0.04 & 0.07 & 0.03 & 0.04 & 0.04 & 0.1 & 0.04 \\
\hline $\mathrm{MgO}$ & 0.5 & 1.3 & 2.84 & 0.28 & 0.81 & 0.29 & 0.27 & 0.66 & 0.26 & 1.53 & 1.16 & 1.98 & 0.65 \\
\hline $\mathrm{CaO}$ & 1.39 & 3.37 & 1.4 & 0.65 & 0.69 & 0.63 & 0.64 & 2.77 & 0.89 & 3.89 & 3.97 & 2.3 & 2.25 \\
\hline $\mathrm{Na}_{2} \mathrm{O}$ & 2.78 & 4.53 & 4.13 & 2.16 & 2.16 & 2.18 & 2.19 & 4.4 & 3.48 & 3.67 & 4.11 & 2.51 & 4.4 \\
\hline $\mathrm{K}_{2} \mathrm{O}$ & 5.89 & 1.47 & 5.42 & 6.38 & 6.34 & 6.67 & 6.56 & 1.07 & 5.08 & 1.3 & 0.73 & 2.16 & 3.04 \\
\hline $\mathrm{P}_{2} \mathrm{O}_{5}$ & 0.11 & 0.09 & 0.02 & 0.1 & 0.17 & 0.19 & 0.18 & 0.09 & 0.1 & 0.09 & 0.04 & 0.09 & 0.07 \\
\hline LOI & 0.49 & 0.65 & 0.45 & 0.59 & 0.54 & 0.58 & 0.54 & 0.5 & 0.6 & 0.55 & 0.46 & 0.56 & 0.23 \\
\hline \begin{tabular}{|l|} 
Total \\
\end{tabular} & 99.96 & 98.64 & 99.87 & 99.47 & 99.81 & 99.98 & 99.99 & 99.89 & 99.89 & 98.57 & 98.04 & 99.58 & 99.88 \\
\hline & & & & & & & & & & & & & \\
\hline \multicolumn{14}{|c|}{ Niggli Values } \\
\hline al & 48 & 44 & 36 & 49 & 45 & 46 & 47 & 39 & 47 & 38 & 40 & 36 & 44 \\
\hline $\mathrm{fm}$ & 8 & 14 & 21 & 8 & 18 & 14 & 14 & 21 & 11 & 23 & 18 & 35 & 13 \\
\hline C & 8 & 17 & 7 & 4 & 4 & 4 & 4 & 15 & 5 & 19 & 20 & 11 & 12 \\
\hline alk & 36 & 25 & 36 & 39 & 33 & 37 & 36 & 25 & 37 & 20 & 21 & 17 & 30 \\
\hline $\mathrm{mg}$ & 0.65 & 0.69 & 0.95 & 0.51 & 0.53 & 0.31 & 0.29 & 0.23 & 0.21 & 0.46 & 0.45 & 0.4 & 0.36 \\
\hline $\mathrm{k}$ & 0.58 & 0.18 & 0.46 & 0.66 & 0.66 & 0.67 & 0.66 & 0.13 & 0.49 & 0.19 & 0.11 & 0.37 & 0.31 \\
\hline si & 395 & 327 & 342 & 475 & 384 & 420 & 409 & 357 & 395 & 319 & 336 & 322 & 352 \\
\hline
\end{tabular}

1, 2, 3. Data from SE Obudu (Ekwueme, 2003); 4, 5, 6, 7.Data from NE Obudu (Ephraim, 2009); 8, 9. Data from NW Obudu (Obioha 2011); 10, 11.Data from NE Obudu (Obiora, 2012); 12,13. Data from SW Obudu (Ukaegbu, 2003)

\section{Geochemical Characteristics}

Several workers have studied the geochemistry of the hornblende biotite gneiss. Table 2 is a compilation of major element and Niggli values from five authors (Ekwueme, 2003, Ukaegbu, 2003, Ephraim, 2009, Obioha 2011, Obiora, 2012) and a review of the trends in the data follows.

The hornblende-biotite gneisses have high $\mathrm{SiO}_{2}$ content ( 68.77 to $72.63 \mathrm{wt} \%$ ). The silica content of the rock is reflected in the Niggli q and si values. The positive $q$ values indicate silica oversaturation. $\mathrm{Al}_{2} \mathrm{O}_{3}$ values range from 12.68 to 15.63 wt \% with $\mathrm{Al}_{2} \mathrm{O}_{3}$ $>\left(\mathrm{CaO}+\mathrm{Na}_{2} \mathrm{O}+\mathrm{K}_{2} \mathrm{O}\right)$ indicating the peraluminious nature of the rocks. $\mathrm{Na}_{2} \mathrm{O}$ and $\mathrm{K}_{2} \mathrm{O}$ contents are relatively high and range from 2.16 to $4.53 \mathrm{wt} \%$ and 0.73 to $6.67 \mathrm{wt} \%$ respectively. This is consistent with the high content of feldspars and biotite in the rock. Analysis from four of the five authors generally indicated $\mathrm{Na}_{2} \mathrm{O}$ higher than $\mathrm{K}_{2} \mathrm{O}$ in their samples. Samples analysed by Ephraim (2009) have higher $\mathrm{K}_{2} \mathrm{O}$ values. $\mathrm{CaO}$ values are variable and range from 0.63 to $3.97 \mathrm{wt} \%$. Total $\mathrm{Fe}$ reported as $\mathrm{Fe}_{2} \mathrm{O}_{3}$ is also variable and ranges from 0.65 to $5.99 \mathrm{wt} \%$, but generally lies between $2-3 w t \%$. The rock is manganese poor as $\mathrm{MnO}$ values are less than $0.1 \mathrm{wt} \%$. Contents of $\mathrm{TiO}_{2}$ and $\mathrm{MgO}$ range from 0.12 to $1.08 \mathrm{wt} \%$ and 0.26 to $2.84 \mathrm{wt} \%$ respectively.

Both sedimentary and igneous parentage have been suggested for the hornblende-biotite gneiss (Ekwueme, 2003; Ephraim 2009). In the al-alk versus Niggli c diagram (Figure 4), most of the rocks plot in the field of igneous rocks. However, data from NE Obudu clearly show a trend extending from the feldspar line towards high al-alk value at nearly a constant $\mathrm{C}$ value. This is also corroborated on the $\mathrm{Na}_{2} \mathrm{O} / \mathrm{Al}_{2} \mathrm{O}_{3}$ versus $\mathrm{K}_{2} \mathrm{O} / \mathrm{Al}_{2} \mathrm{O}_{3}$ discrimination diagram after Garrels and Mackenzie (1971) (Figure 5), where most of the samples also plot in the meta-igneous field with the data from NE Obudu plotting in the metasedimentary field albeit, close to the boundary. This trend could be interpreted as the protolith being mainly of igneous parentage with minimal sedimentary input.

To define the chemical affinity of the rocks, the data were plotted on TAS diagram, (Figure 6) where the samples clearly plot in the sub-alkaline series field. Further discrimination of this field using the FMS diagram of Miyashiro (1974; Figure 7), had some samples plotting in the tholeiitic series and the rest in the calc-alkaline series. On the Jensen diagram (Figure 8), only two samples which had $\mathrm{Fe}_{2} \mathrm{O}_{3}$ values of $1 \mathrm{wt} \%$ and less plotted on the calc-alkaline field. The rest of the data plotted on the tholeiite field. 


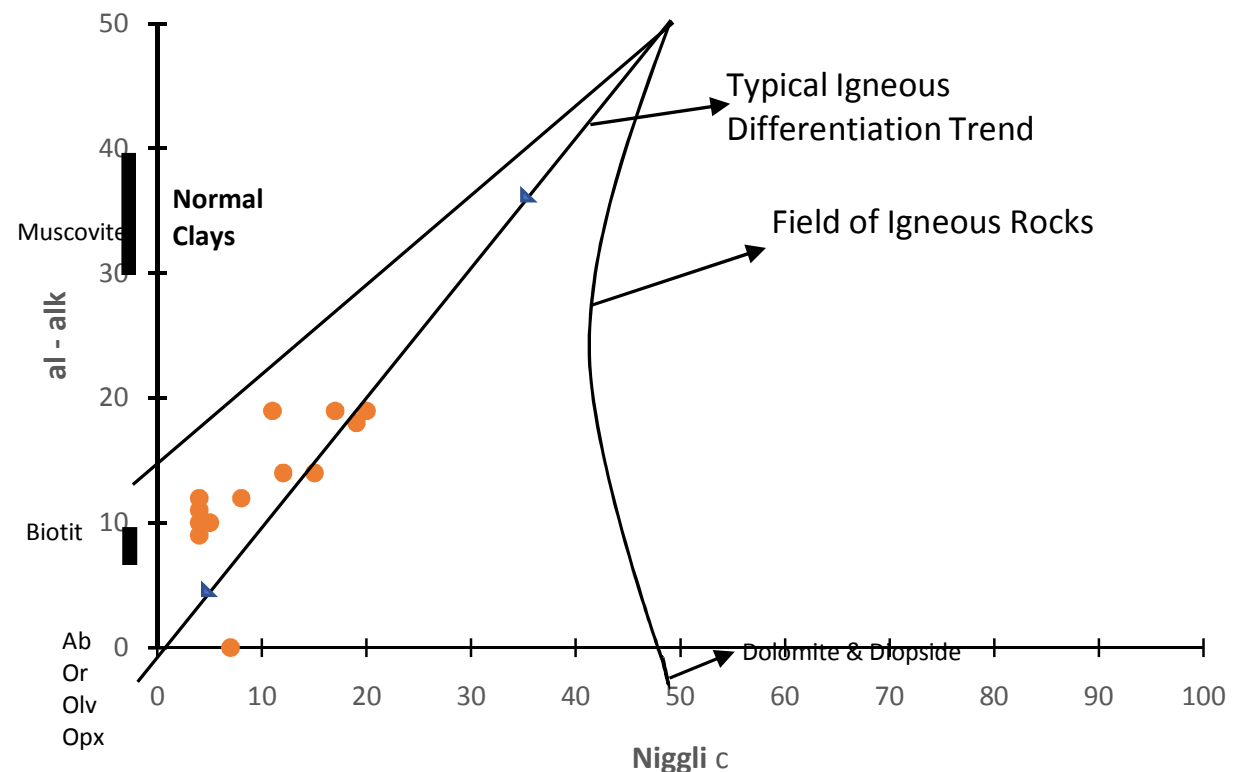

Figure 4. Niggli al-alk against Niggli c Plot (after Leake and Singh, 1986) showing the variation trends in the hornblende biotite gneisses.

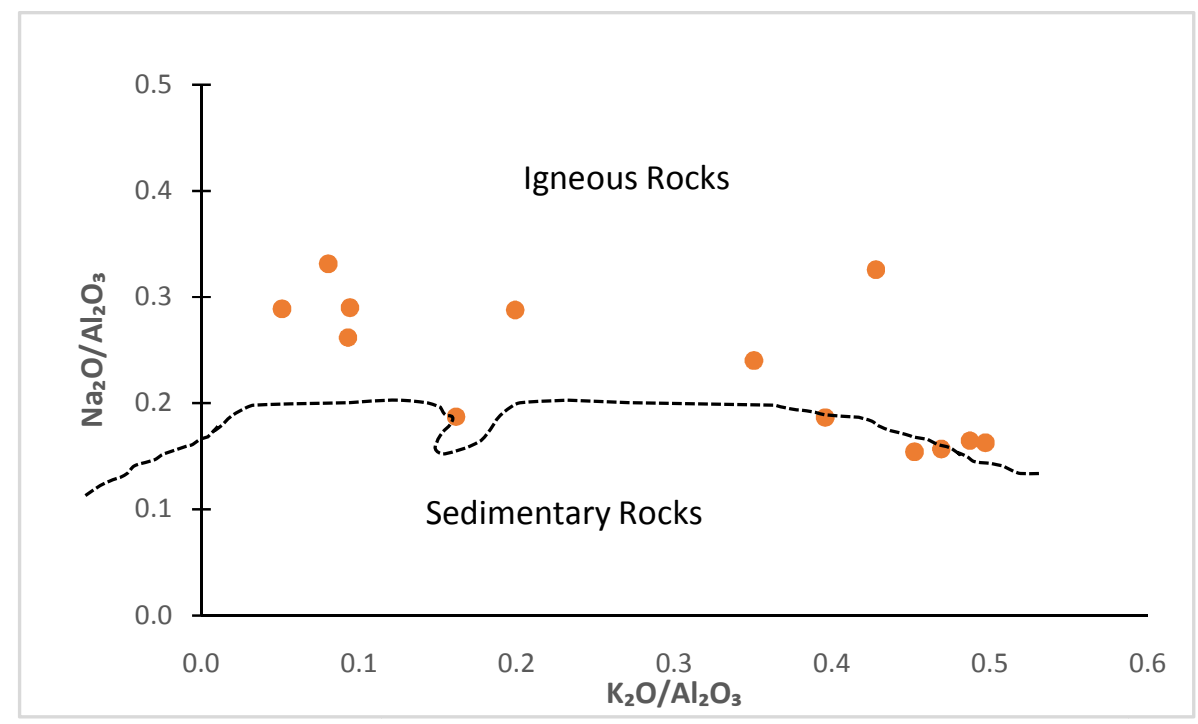

Figure 5. $\mathrm{Na}_{2} \mathrm{O} / \mathrm{Al}_{2} \mathrm{O}_{3}$ versus $\mathrm{K}_{2} \mathrm{O} / \mathrm{Al}_{2} \mathrm{O}_{3}$ discrimination diagram for hornblende biotite gneiss of Obudu (After Garrels and Mackenzie,1971) 


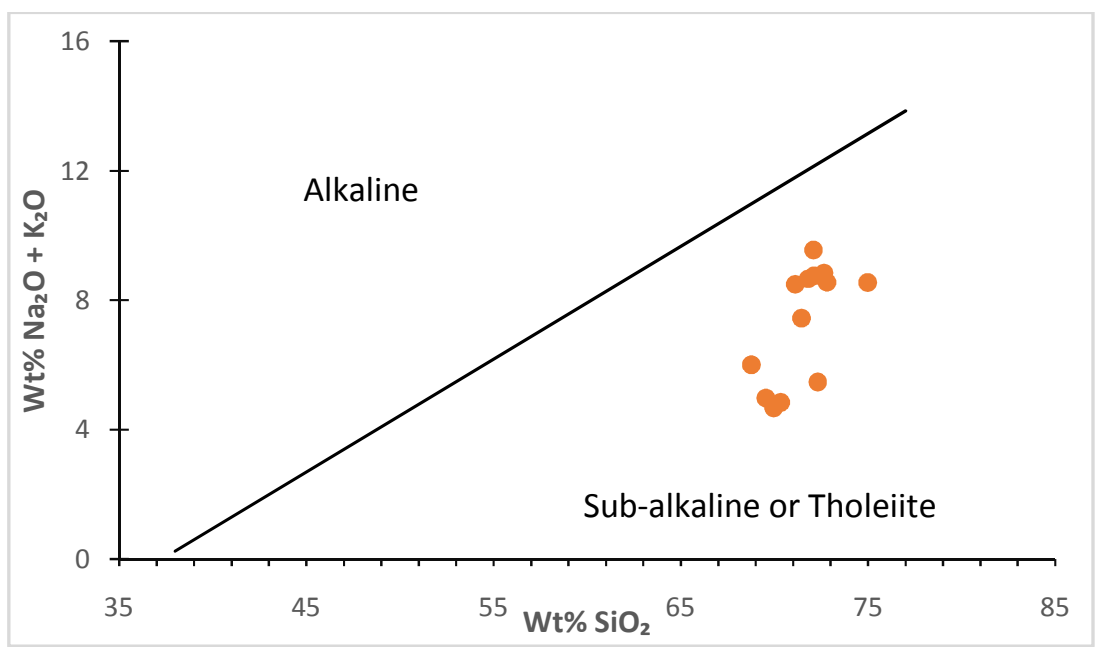

Figure 6.: Plot of hornblende biotite gneiss data on TAS diagram (Boundary lines from Rickwood 1989)

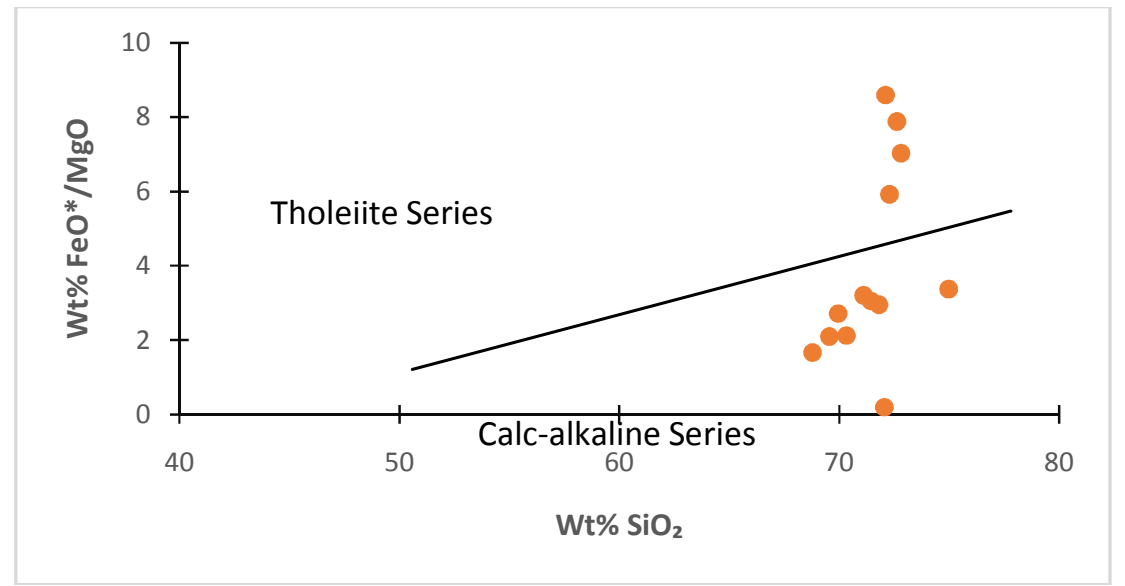

Figure 7.: Plot of hornblende biotite gneiss data on FMS diagram (after Miyashiro, 1974)

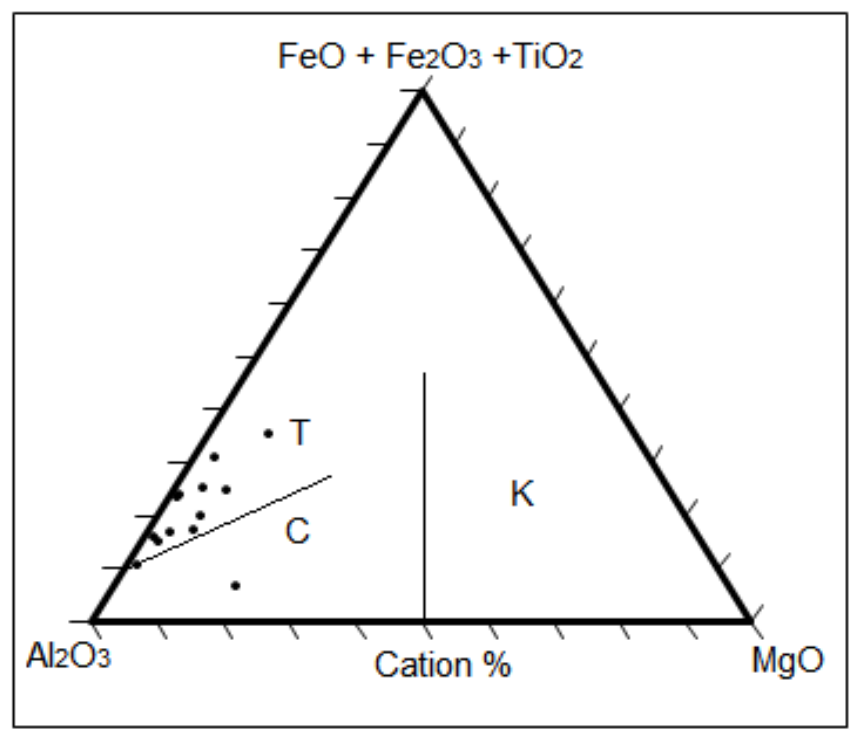

Figure 8.: Plot of hornblende biotite gneiss data on the Jensen diagram (after Jensen, 1976). $T=$ Tholeiite, $C=$ Calcalkaline, K = Komatiite (modified using Tri-plot Graham and Midley, 2000) 


\section{Summary and Conclusions}

The hornblende-biotite gneiss that occurs in the Obudu plateau have experienced high grade metamorphism of the upper amphibolite to granulite facies. This is indicated by the presence of sillimanite and orthopyroxene in some of the samples. The rocks have undergone partial melting, resulting in the formation of abundant leucosomes, which are generally parallel to the foliation of the host rocks and the presence of structures that are characteristic of migmatitic terrains such as augen structures and contorted foliation. The gneisses are generally enriched in silica, alumina and alkalis. Geochemical studies show that the protoliths of the rocks are calc-alkaline to tholeiitic in nature and that the protoliths may be of a mixed nature comprising both igneous and sedimentary rocks.

\section{ACKNOWLEDGEMENTS}

The authors are grateful to Dr Christopher Adamu and Mr Emmanuel Iroka for their immense help during the field aspect of this research. The personnel of the thin section laboratory, Department of Geology, University of Calabar are also appreciated for their assistance.

\section{REFERENCES}

Dada, S. S., 1998. Crust-forming ages and Proterozoic crustal evolution in Nigeria: a reappraisal of current interpretations. Precambrian Res. 87: 65-74.

Ekwueme, B. N., 1990. Rb-Sr ages and petrological features of Precambrian rocks from the Oban Massif, Southeastern Nigeria. Precambrian Res. 47: 271-286.

Ekwueme, B. N., 1994. Structural features of southern Obudu Plateau, Bamenda Massif, SE Nigeria: preliminary interpretations. J. Min. Geo. 30(1) 45-59.

Ekwueme, B.N., 2003. The Precambrian geology and evolution of the southeastern Basement complex. University of Calabar press, Nigeria, $135 p$.

Ephraim, B. E., 2005. Petrology and geochemistry of basement rocks Northeast of Obudu, Bamenda massif, S.E Nigeria. Ph.D Thesis, University of Calabar, 367pp

Ephraim, B. E., 2009. Compositional features and petrogenetic characteristics of migmatitic rocks of northeast Obudu Bamenda massif, southeastern Nigeria. J. Min. Geo. 45(1): 1-11.

Garrels, R. M., and Mackenzie, F T., 1971. Evolution of metasedimentary rocks. Norton and Company, New York, 394pp.
Grant, N. K., 1970. Geochronology of Precambrian basement rocks from Ibadan, southwestern Nigeria. Earth Planet. Sci. Lett. 10:29-38.

Graham, D. J., and Midgley, N. G., 2000. Graphical representation of particle shape using triangular diagrams: An excel spreadsheet method. Earth Surf. Process. Landforms 25: 1473-1477.

Jensen, L. S., 1976. A New Cation Plot for Classifying Subalkalic Volcanic Rocks. Ontario Div. Mines, MP 66.

Leak, B. E. and Singh. D., 1986. The Delaney Dome formation, Connemara, W. Ireland, and geochemical distinction of ortho- and paraquartzofeldspathic rocks. Miner. Mag. 50: 205215.

Miyashiro, A., 1974. Volcanic rock series in Island Arcs and active continental margins. Am. J. Sci., 274: 321-355.

Obioha, Y.E. and Ekwueme, B.N., 2011. Petrology and chemical composition of gneisses of northwest Obudu Plateau, southeastern Nigeria. Global. J. Pure and Appli. Sci., 17(2): 215-226.

Obiora, S. C., 2012. Chemical characterisation and tectonic evolution of hornblende-biotite granitoids from the Precambrian basement complex around Ityowanye and Kastina -Ala, southeastern Nigeria. J. Min. Geol. 48(1): 13-29.

Orajaka, S. O., 1964. Geology of the Obudu Area, Ogoja Pronvince, Eastern Nigeria. Le Naturaliste Canadien, 91(3): 73-78.

Rahaman, M. A., 1988. Recent advances in the study of the basement complex of Nigeria. In P.O. Oluyide (Editor), Precambrian Geology of Nigeria. Geol.Surv. Nigeria Publ. pp11-43

Rahaman M. A., and Lancelot J. R., 1984. Continental crust evolution in SW Nigeria: constraints from $\mathrm{U} / \mathrm{Pb}$ dating of pre-Pan-African gneisses. In Rapport d'activite 1980-1984 Documents et Travaux du Centre Geologique et Geophysique de Montpellier. pp 41-50.

Rickwood, P.C., 1989. Boundary lines within petrologic diagrams which use oxides of major and minor elements. Lithos 22: 247-263

Toteu, S. F., Penaye, J., and Djomani, Y. P., 2004. Geodynamic evolution of the Pan-African belt in central Africa with special reference to Cameroon. Canadian Jour. Earth Sci. 41: 7385.

Ukaegbu V. U., 2003. The Petrology and Geochemistry of Parts of Obudu Plateau, Bamenda Massif, 
Southeastern Nigeria. Ph.D. Thesis, Univ. of Port Harcourt, aNigeria, $321 \mathrm{pp}$

Ukwang, E. E., Ekwueme, B. N., and Horsley, R. J., 2003. Petrology of the granulite facies rocks in Ukwortung area of Obudu plateau, southeastern Nigeria. Global. J. Geol. Sci., 1(2): 159-167.

Ukwang, E.E, Ekwueme, B.N. and Kröner, A., 2012. Single zircon evaporation ages: Evidence for the
Mesoproterozoic crust in S.E. Nigerian basement complex. Chin. J. Geochem. 31: 4854.

Woakes, M., Rahaman, M. A., and Ajibade, A. C. 1987. Some metallogenetic features of the Nigerian basement. Journal of African Earth Sciences , 6(5): 655-664. 